\title{
Financial Literacy of Professional and Pre-Service Teachers in the Philippines
}

Montalbo Imelda C*, Pogoy Angeline M, Villarante Gwendelina A, Pepito Genalen M

Department of Economics, Cebu Normal University, Cebu, Philippines

\begin{abstract}
A financial literacy survey among one thousand, nine hundred twenty four (1924) professional and pre-service teachers across different regions of the country is the basis of the study. With the permission standardized tool was used to gather data from the randomly selected respondents from different public and private schools, colleges and universities from Luzon, Visayas and Mindanao. The findings revealed that both professional and pre-service teachers have very low basic and sophisticated financial literacy skills. Thus, financial illiteracy is common among educators which reflect their students' financial literacy skills and the economic condition of the majority of the Filipino people. Curriculum inclusion of financial education to both basic and higher education is recommended to improve the financial knowledge, behaviour and attitudes among teachers and students which, in turn, spells a better economic growth and development of the country.
\end{abstract}

Keywords: Financial literacy; Professional teachers; Pre-service teachers

\section{Introduction}

In recent years, developed countries have become progressively more concerned about the level of financial literacy of their citizens. Strong interest in improving financial literacy has moved to the forefront of public policy concerns worldwide. It has become a key priority for global policymakers who realize the effect that individual financial decisions can have on national level as well as on global scale [1].

Financial literacy is knowledge and understanding of financial concepts and risks, motivation and confidence to apply such knowledge and understanding in order to make effective decisions regarding the range of financial contexts and also to improve the financial well-being of individuals and society, and to enable participation in the economic life [2]. New evidence finds that financial illiteracy in the United States population is widespread, particularly among vulnerable demographic groups such as the least educated, women and minorities [3].

The UK Financial Services Authority concluded that the younger people, those are in low social classes and the people who are with low incomes were the least sophisticated financial consumers [4]. In a Japanese Consumer Finance Survey, 71\% of adults knew little about equity and bonds, and more than $50 \%$ lacked any knowledge of financial products [5]. Financial knowledge is weak as evidenced in a German survey conducted by Commerzbank AG in 2003. It found out that $80 \%$ of the respondents were confident about understanding financial issues, but only $42 \%$ could answer half of the financial survey questions. Moreover, 2.5 billion adults in Africa, Asia, Latin America and Middle East do not use formal financial services to save or borrow [6]. Many remote and northern communities in Canada lack access to financial services. Polish Financial Supervision Authority noted that Poles have sufficient numerical skills but limited knowledge and understanding of how financial markets work [6]. Such financial literacy reviews among nations show that levels of financial knowledge are relatively low and they are poorly informed about financial product and practices [3]. Similar findings were disclosed in the comparative study of Atkinson and Messy [5] across countries surveyed wherein lack of financial knowledge was highlighted among a sizeable proportion of the population, attitudes on financial literacy vary and a considerable room for improvement in terms of financial behaviour are noted. Furthermore, World Bank [7] supports that the common assessment across countries on the level of understanding of financial issues by individual is too low and associated with behaviour that has consequences for individuals [8]. This global scenario on financial illiteracy presents a barrier to economic growth and financial inclusion.

In the MasterCard Index of Financial Literacy Survey 2013, Philippines has 68 overall financial literacy index with low levels of financial literacy from the demographic of 30-year-olds who are married. Such situation is evident with marriage and increasing family obligations, such as household expenses, education and financial commitments. Based on the Philippine Financial Literacy Advocacy 2013 Report, most of the Filipinos have good knowledge on financial concept of investments, but they lack in understanding the concept of healthy budget and inflation. More importantly, the study showed that only $49 \%$ of Filipinos put money in bank accounts every month. Among those who do, only save an average of $6 \%$ which is below the minimum suggested $10 \%$.

Financial literacy is now acknowledged globally as an important element for economic and financial stability and development. Trends support the rising global interest in financial literacy as a key to life skill [9]. Existing empirical evidence shows that adults in both developed and emerging economies who have been exposed to financial education are subsequently more likely than others to save and plan for retirement $[3,10]$. Those with higher financial literacy are better able to manage their money, participate in the stock market and more likely to invest [11]. Moreover, those who have greater financial knowledge are more

*Corresponding author: Imelda CM, Department of Economics, Cebu Normal University, Cebu City, Philippines, Tel: +63322539611; E-mail: gelinempogoy@gmail.com

Received August 16, 2017; Accepted October 26, 2017; Published November 02, 2017

Citation: Imelda CM, Angeline MP, Gwendelina AV, Genalen MP (2017) Financial Literacy of Professional and Pre-Service Teachers in the Philippines. J Glob Econ 5: 267. doi: 10.4172/2375-4389.1000267

Copyright: (c) 2017 Imelda CM, et al. This is an open-access article distributed under the terms of the Creative Commons Attribution License, which permits unrestricted use, distribution, and reproduction in any medium, provided the original author and source are credited. 
likely to accumulate higher amounts of wealth [12]. Financially literate consumers can make more informed decisions and demand higher quality services which will encourage competition and innovation in the market [2].

To date, no single study has ever been conducted in the Philippine setting to get the actual measure of financial literacy among educators, whether and how this particular group of professionals are making informed decisions around their finances. This study examines the level of financial literacy among pre-service teachers and professional teachers in terms of numeracy, compound interest, inflation, time value of money, money illusion and risk diversification. Evidence-based findings of the study will be a basis for recommendation in addressing the need of pre-service teachers to include financial education as part of the national education curriculum, and the need of professional teachers for the right training to provide financial education.

This study examined the level of financial literacy of public and private pre-service teachers and professional teachers in the Philippines. Specifically it sought to measure their understanding on the basic financial concepts in terms of numeracy, compound interest, inflation, time value of money, money illusion and functions of stock market. It also sought to measure their understanding on sophisticated financial knowledge on mutual funds, interest rates, stocks, bonds, mutual funds, long period return of money, fluctuations and risk diversifications.

\section{Review of Related Studies}

Financial literacy is about understanding money and finances and being able to confidently apply that knowledge to make effective financial decisions [13]. However, Global OECD 2005 financial statistics shows huge gaps in the financial knowledge and skills of individuals across countries-gaps that make individuals vulnerable to making poor decisions about their money [14].

Eighty-nine percent of the first year college students from the five colleges and universities across United States scored poorly, equivalent of a "C" or below in basic financial literacy [15]. Four in ten students did not know the definition of "net pay" and too many students could not correctly identify the kinds of items that appear on a pay check stub. This showed that students are not familiar with life skills that they need and don't have a good knowledge base to work from. Likewise, Department of Education in Poland noted that $46 \%$ of the Poles respondents preferred to spend money rather than save it for [14]. Just $63 \%$ of them have a bank account, $25 \%$ have credit cards and only $18 \%$ have a saving account. Similarly, study of Ramasawmy et al. [16] reports that the management students of Mauritius have a medium level of knowledge and skills in savings and borrowings. This implies that poor savings is visible among respondents. Research in behaviour finance suggests that many households do not make optimal savings and this may lead to unacceptable standards of living and economic anxiety [11]

National council of Economic Education (NCEE) periodically surveys on economics, money, interest rates, inflation and personal finance among high school students and working-age adults in US population. Tallied results revealed that adults earned an average score of $\mathrm{C}$, while the high school population fared even worse, with most receiving failing marks [12], Such finding among American population has been confirmed by Hilgert et al. [17] who investigates respondents between 18 to 97 years old about their saving patterns, credit, mortgages, and general financial management. The study discovered that respondents could answer only two-thirds of the questions correctly. They were best informed on mortgages $(81 \%$ correct), saving patterns (67\% correct), credit cards (65\% correct), and general financial management $(60 \%$ correct). Moreover, respondents were less knowledgeable about mutual funds and stock market; only one-half knew that mutual funds do not pay a guaranteed rate of return, and 56\% knew that "over the long-term, stocks have the highest rate of return on money invested".

The huge gap on financial knowledge and skill is manifested in 2005 Australian Financial Literacy Survey where $67 \%$ of the respondents indicated that they understood the concept on compound interest, yet when they were asked to solve a problem using the concept, only $28 \%$ had a good level of understanding. Specific results of from third world country like South Africa showed that knowledge and understanding of mathematical concepts related to finance is quite low, with only $26 \%$ of respondents showing basic understanding of the impact of inflation, and high numbers reporting they do not know the answers for questions about simple and compound interest [14].

Researchers also set out to measure budget, keeping track and choosing financial products and services. Outcomes indicated that $49 \%$ of all Canadian adults do not have a budget at all, while $57 \%$ of Canadians between the ages 18 and 29 do not have a budget. When asked how they could cover a $\$ 500$ expense, $45 \%$ say they would use credit or debt (FCAC-OECD, 2011). Most Canadians are reasonably okay in making ends meet but they are not great at planning ahead or staying informed. Lusardi and Mitchell [18] opined that lack of planning is tantamount to lack of saving. Moreover, other issues exist in other OECD countries, where lack of access to financial services is a problem. Many remote and northern communities in Canada lack access to financial services, with only 3 out of 25 communities had access to a bank branch in 2009 . In Zambia and six other African countries, only $29 \%$ of adults have a bank account and 50\% use no financial products at all. Indeed, lack of financial literacy if regularly tied to lack of access to financial services or failure to use them even when they are available.

There are some key differences between men and women when it comes to money-related choices. Lusardi and Mitchell [3] revealed that gender differences in financial knowledge do exist based on survey questions on basic numeracy, interest rates, inflation and risk diversification. She further explained that women tend to say they know less or they also tend to be more cautious when answering test questions than men, preferring to say that they don't know the answer rather than taking a guess. Furthermore, she clarified that women without the knowledge to make sound financial decisions are particularly vulnerable and yet they play an important role in the financial sector as consumers and managers of household budgets. Hung and Yoong [11] concluded that gender does matter when it comes to financial literacy, because women with lower financial literacy levels are prone and could end up participating less in financial markets, paying higher costs for services and putting higher risks for poverty. Additionally, financial literacy declines rapidly with age, and is particularly low among older women [3].

Researchers are trying to link financial literacy and economic behaviour. Lusardi and Mitchell [3] suggest that those who are more educated are much more likely to answer the questions correctly. They further showed that financial literacy is highly correlated with school exposure to economics. Those who studied economics in high school, college or at higher levels were much more likely to display higher levels of financial literacy later in life [19]. Using the 2004 HR Survey, it revealed that those who are more financially knowledgeable are also much more likely to have thought about retirement [3]. Additionally, 
the study of Calvert et al. [20] confirmed that more financially sophisticated households are more likely to buy risky assets and invest more efficiently.

In low and middle income countries, gaps on financial literacy and financial products have widened in the recent years due to the increase in access to financial products and services, while financial literacy, financial education as well as skills enhancement is lagging well behind [8]. In low income countries in particular, access to financial services is very limited for a very large share of the poor population living in the rural areas.

Strong and rising interest in the level of financial literacy worldwide and in educational interventions to improve it have been seen in the recent years. In 2003, UK developed a National Capability Strategy to establish a road map for delivering change in financial capability of the UK population. USA, New Zealand, Australia and Canada follow suit in developing national strategies to improve financial literacy levels among their respective population. USA developed Jumpstart Coalition for Personal Financial Literacy. According the National Council on Economic Education (2005), 38 states now have personal finance standards built into their state education systems, and 21 of these states require clearly that the standards be implemented [21]. Particularly in Australia, effective integration of financial education into school education is the cornerstone to bringing about the long-term generational change in financial knowledge, attitudes and behaviour [13]. In 2009, Canada established its Task Force on Financial Literacy with lifelong learning as a priority based on the unique needs of its population [14]. The motivation behind is universal: through national leadership and collaboration across sectors, countries can develop sustainable and effective approaches in improving financial literacy among the entire population [14].

\section{Research Methodology}

The study made use of descriptive survey design to examine the level of financial literacy of public and private pre-service teachers and professional teachers in the Philippines.
A total of one thousand nine hundred twenty-four $(1,924)$ respondents throughout the country were the respondents of this study. There were one thousand one $(1,001)$ professional teachers and nine hundred twenty-three pre-service teachers (923) randomly selected from the big island groups of the country such as Luzon, Visayas and Mindanao.

With the permission from the author, Lusardi and Mitchell [22], the instrument Financial Literacy Survey was used in this study. The questions measured the understanding of basic and sophisticated financial literacy. Data were gathered through the responses of the questionnaires and personal interviews of the respondents.

\section{Results and Discussion}

\section{Demographic profile}

Around 1,924 teachers from public and private schools of Luzon, Visayas and Mindanao of the Philippines took the Basic and Sophisticated Financial Literacy Survey. There were 1,001 professional teachers and 923 pre-service teachers in which 599 of them are males and 1,325 of them are females. The professional teachers whose ages range from 31-40 years old and have been in the teaching profession for 5 to 25 years with an average monthly salary of Php20,000.00. On the other hand, the pre-service teachers who are currently enrolled in the student teaching program, have parents whose educational attainment is college level with an average monthly income between Php11,000.00 to PhpP20,000.00.

Table 1 presents the number and percentages of professional and pre-service teachers who passed the basic and sophisticated financial literacy survey.

Out of the 1001 professional teachers only $27 \%$ of them passed the basic financial literacy survey. Among the 923 pre-service teachers, less than one-fourth $(1 / 4)$ of them passed the basic financial literacy survey. Around $60 \%$ of the professional and pre-service teachers were able to read and compute correctly the basic numeracy problem, however, they failed to understand, process and assess the given information

\begin{tabular}{|c|c|c|c|c|c|c|c|c|c|c|c|c|}
\hline & \multicolumn{12}{|c|}{ Professional Teachers } \\
\hline & \multicolumn{6}{|c|}{ Basic Financial Literacy } & \multicolumn{6}{|c|}{ Sophisticated Financial Literacy } \\
\hline & \multicolumn{2}{|c|}{ Male } & \multicolumn{2}{|c|}{ Female } & \multicolumn{2}{|c|}{ Total } & \multicolumn{2}{|c|}{ Male } & \multicolumn{2}{|c|}{ Female } & \multicolumn{2}{|c|}{ Total } \\
\hline & f & $\%$ & f & $\%$ & $f$ & $\%$ & f & $\%$ & f & $\%$ & $\mathbf{F}$ & $\%$ \\
\hline Luzon & $\begin{array}{c}38 \\
(116)\end{array}$ & 32.75 & $\begin{array}{c}44 \\
(188)\end{array}$ & 23.40 & $\begin{array}{c}82 \\
(304)\end{array}$ & 26.97 & $\begin{array}{c}18 \\
(116)\end{array}$ & 15.51 & $\begin{array}{c}8 \\
(188)\end{array}$ & 4.25 & $\begin{array}{c}26 \\
(304)\end{array}$ & 8.55 \\
\hline Visayas & $\begin{array}{c}34 \\
(116)\end{array}$ & 29.31 & $\begin{array}{c}67 \\
(222)\end{array}$ & 30.18 & $\begin{array}{c}101 \\
(338)\end{array}$ & 29.88 & $\begin{array}{c}15 \\
(116)\end{array}$ & 12.93 & $\begin{array}{c}7 \\
(222)\end{array}$ & 3.15 & $\begin{array}{c}22 \\
(338)\end{array}$ & 6.51 \\
\hline Mindanao & $\begin{array}{c}40 \\
(128)\end{array}$ & 31.25 & $\begin{array}{c}44 \\
(231)\end{array}$ & 19.04 & $\begin{array}{c}84 \\
(359)\end{array}$ & 23.39 & $\begin{array}{c}3 \\
(128)\end{array}$ & 2.34 & $\begin{array}{c}8 \\
(231)\end{array}$ & 3.46 & $\begin{array}{c}11 \\
(359)\end{array}$ & 3.06 \\
\hline Total & $\begin{array}{c}112 \\
(360)\end{array}$ & 31.11 & $\begin{array}{c}155 \\
(641)\end{array}$ & 24.18 & $\begin{array}{c}267 \\
(1001)\end{array}$ & 26.67 & $\begin{array}{c}35 \\
(360)\end{array}$ & 9.72 & $\begin{array}{c}23 \\
(641)\end{array}$ & 3.59 & $\begin{array}{c}58 \\
(1001)\end{array}$ & 5.79 \\
\hline
\end{tabular}

\begin{tabular}{|c|c|c|c|c|c|c|c|c|c|c|c|c|}
\hline & \multicolumn{12}{|c|}{ Pre-service Teachers } \\
\hline & \multicolumn{6}{|c|}{ Basic Financial Literacy } & \multicolumn{6}{|c|}{ Sophisticated Financial Literacy } \\
\hline & \multicolumn{2}{|c|}{ Male } & \multicolumn{2}{|c|}{ Female } & \multicolumn{2}{|c|}{ Total } & \multicolumn{2}{|c|}{ Male } & \multicolumn{2}{|c|}{ Female } & \multicolumn{2}{|c|}{ Total } \\
\hline & $f$ & $\%$ & f & $\%$ & f & $\%$ & f & $\%$ & f & $\%$ & $\mathbf{F}$ & $\%$ \\
\hline Luzon & $\begin{array}{c}30 \\
(86)\end{array}$ & 34.88 & $\begin{array}{c}37 \\
(189)\end{array}$ & 19.57 & $\begin{array}{c}67 \\
(275)\end{array}$ & 24.36 & $\begin{array}{c}10 \\
(86)\end{array}$ & 11.62 & $\begin{array}{c}9 \\
(189)\end{array}$ & 4.76 & $\begin{array}{c}19 \\
(275)\end{array}$ & 6.91 \\
\hline Visayas & $\begin{array}{c}15 \\
(74)\end{array}$ & 20.27 & $\begin{array}{c}82 \\
(287)\end{array}$ & 28.57 & $\begin{array}{c}97 \\
(361)\end{array}$ & 26.87 & $\begin{array}{c}3 \\
(74)\end{array}$ & 4.05 & $\begin{array}{c}16 \\
(287)\end{array}$ & 5.57 & $\begin{array}{c}19 \\
(361)\end{array}$ & 5.26 \\
\hline Mindanao & $\begin{array}{c}9 \\
(79)\end{array}$ & 11.39 & $\begin{array}{c}44 \\
(208)\end{array}$ & 21.15 & $\begin{array}{c}53 \\
(287)\end{array}$ & 18.47 & $\begin{array}{c}6 \\
(79)\end{array}$ & 7.59 & $\begin{array}{c}5 \\
(208)\end{array}$ & 2.40 & $\begin{array}{c}11 \\
(287)\end{array}$ & 3.83 \\
\hline Total & $\begin{array}{c}54 \\
(239)\end{array}$ & 22.59 & $\begin{array}{c}163 \\
(684)\end{array}$ & 23.83 & $\begin{array}{c}217 \\
(923)\end{array}$ & 23.51 & $\begin{array}{c}19 \\
(239)\end{array}$ & 7.95 & $\begin{array}{c}30 \\
(684)\end{array}$ & 4.39 & $\begin{array}{c}49 \\
(923)\end{array}$ & 5.31 \\
\hline
\end{tabular}

Table 1: Financial literacy of professional and pre-service teachers in the Philippines. 
effectively. Most of the teachers have heard investment terms as stocks, bonds, mutual funds, stock market and inflation, but they really do not know how these work. They were afraid of scams and untrustworthy insurance providers. They lacked the ability to comprehend the complexity of these financial products and evaluate and apply it accordingly [23]. This means that they have limited knowledge and understanding on basic financial ideas on numeracy, compound interest, inflation, time value of money, money illusion and functions of stock market, and how it is applied in the financial market. This implies that their education and training didn't equip them to understand and apply basic financial computations. Similar findings are noted by Rychwalski [14] that overall level of financial literacy of Polish was quite low and how financial markets work was not well understood. All these findings confirmed the studies in psychology and marketing that many people are not numerate and have difficulty grasping percentages and working with fractions $[24,25]$.

Almost one-third of the male professional teachers had passed the basic financial literacy survey while only $24 \%$ of the female professional teachers got the passing average score of 4 . This showed that men had better understanding on financial concepts than women. This means that women had inadequate information to make sound financial decisions, yet they play an important role as managers in family budgets. Lusardi and Mitchell [22] opined that women particularly older women are vulnerable and at risk of poor financial outcomes. Women are saying they know less and do not take risk. Low literacy among women is established in other surveys covering younger or representative groups of the US population [12,18]. Lusardi and Mitchell [12] revealed that there is a financial knowledge gap between men and women when it comes to money-related choices [22].

In both professional and pre-service teachers, it is observed that male groups from Luzon had the greatest number of passing percentage. This means they received financial information and took full advantage of the financial products and services offered in market considering that they live in (Luzon) an urban area, the hub of banking products and services in the country.

The fact that professional and pre-service teachers of Mindanao got the lowest number of passing percentage is disturbing. This means that many remote areas in Mindanao lack access to financial services. Such problems exist in many low-income countries where access to financial services is very limited, and poverty is prevailing for a large share of the population living in the rural areas [8]. Moreover, lack of access is not only an inconvenience, it is also a significant barrier to financial inclusion [26].

Only $6 \%$ of the professional teachers and $5 \%$ of the pre-service teachers passed the Sophisticated Financial Literacy Survey. This alarmingly low passing percentage for both male and female groups simply revealed that they cannot identify and evaluate complex financial products and services that are available in the market such as mutual funds, fluctuations and risk diversification and their functions in the stock market. Likewise, teachers do not have the ability to interpret and apply the given information to their day-to-day experiences and therefore, they do not take risks. According to Willis [27] most consumers have great difficulty dealing with and understanding numbers and terms when the amounts substantially exceed their daily experience. The teachers in the Philippines need greatest support to improve their abilities to fully understand this range of financial services in order to fully participate in economic life. World Bank [8] has conceptualized an important move from financial literacy (with its focus on knowledge and skills) to capability (with its focus on behavior and results) through financial education.

Table 2 shows the mean scores and the category or level of performance of the professional and pre-service teachers in the basic and sophisticated financial literacy survey.

Although, both professional and pre-service teachers assessed themselves as average in their personal financial knowledge, they have mean scores of 2.79 and 2.62, which are below the baseline level of performance (average score of 4 ) in order to pass the basic financial literacy survey. They have the skill on basic number numeracy, like doing simple calculation related to compounding interest rates, but they lack the ability to apply their stored knowledge and skill to real-life circumstances in the context of a simple financial decision.

This finding reveals that teachers are unskilled with the basic economic concepts on numeracy and compound interest. They also lack the capability to evaluate financial information which is essential in making decision on money, saving, spending, investing and credit. They are under-informed on the meaning of inflation or deflation as well as its causes and effects. These results are uncomfortable considering that several teachers in the study have been in the profession for 15-20 years, thus must have made several financial decisions in life and are just few years from retirement which is very crucial in their economic capacity. Similar challenges are faced with Australian workers and retirees in directing their complex financial products and services required for retirement planning [28].

In Sophisticated Literacy Survey, both professional and pre-service teachers have very low financial literacy with the scores of about 33\% below the passing mean score of 6 . This is expected since they got $50 \%$ below the expected passing score for basic financial literacy. They have very limited knowledge on company stocks and bonds. They cannot tell the relationship between interest rates and bonds as well as identify the high returns of these funds. The fact that teachers can't explain financial

\begin{tabular}{|c|c|c|c|c|c|c|c|c|}
\hline & \multicolumn{4}{|c|}{ Professional Teachers } & \multicolumn{3}{|c|}{ Pre-Service Teachers } & \multirow[b]{2}{*}{ Category } \\
\hline & $\begin{array}{c}\text { Basic Financial } \\
\text { Literacy } \\
\text { Mean }\end{array}$ & Category & $\begin{array}{c}\text { Sophisticated } \\
\text { Financial Literacy } \\
\text { Mean }\end{array}$ & Category & $\begin{array}{c}\text { Basic Financial } \\
\text { Literacy } \\
\text { Mean }\end{array}$ & & $\begin{array}{c}\text { Sophisticated } \\
\text { Financial Literacy } \\
\text { Mean }\end{array}$ & \\
\hline Luzon & 2.83 & Low & 2.84 & Very Low & 2.42 & Low & 2.76 & Very Low \\
\hline Visayas & 2.88 & Low & 2.88 & Very Low & 2.85 & Low & 2.79 & Very Low \\
\hline Mindanao & 2.67 & Low & 2.80 & Very Low & 2.58 & Low & 2.69 & Very Low \\
\hline Total & 2.79 & Low & 2.84 & Very Low & 2.62 & Low & 2.75 & Very Low \\
\hline \multicolumn{5}{|c|}{$\begin{array}{l}\text { Basic Financial Literacy: } \\
\text { Very High }=5 \\
\text { Average }=4 \text { (passing score) } \\
\text { Low }=2-3 \\
\text { Very Low }=0.1\end{array}$} & \multicolumn{3}{|c|}{$\begin{array}{l}\text { Sophisticated Financial Lite } \\
\text { Very High }=8 \\
\text { Average }=6 \text { (passing score) } \\
\text { Low }=4-5 \\
\text { Very Low }=0-3\end{array}$} & \\
\hline
\end{tabular}

Table 2: Financial literacy mean scores of the professional and pre-service teachers. 
risk is evident that they haven't taken a risk in investing their money in stocks or bonds. In other words, majority of the professional and preservice teachers are not financially sophisticated.

The result proved that the respondents are unaware with the growing range of financial products and services available in the market. They failed to maximize the uses of these financial services in making good financial decisions and plan for their future. This means that the present curricula in basic education and higher education do not equip the teachers as well as the students' financial knowledge and skills to prepare them for life. This financial illiteracy has critical implications on the way teachers manage their income, use credit effectively, secure their financial wellbeing and make good financial decisions in life. This will also predict the behaviour and attitude of their students.

In the Philippine setting, it has become a culture that after graduation, students seek for a job. The employability of most of the graduates is more acceptable and practiced in the country rather than employer ability or engaging into entrepreneurship after graduation. As reported by Philippine Statistics Authority [29], the country has a high poverty incidence of $26 \%$ and great income gap between the rich and the poor at $29 \%$. Majority of the population belongs to the low economic level, thus do not have the capacity to invest their money. Such growing gap is making economic growth of the country less sustainable (World Economic Forum, 2014)

These findings merit for a policy recommendation for inclusion of financial education for basic and higher education. Almost all of the professional teachers in the survey recommended for trainings, seminars and conferences on financial literacy to advance their financial knowledge and skills. According to Mitchell and Lusardi [12], schools and workplaces obviously offer convenient training grounds. Inclusion of financial literacy courses in all curricula is suggested, thus students must be exposed to basic economics and finance in order to improve their level of financial knowledge at a young age [16]. Young children increased their financial capability when they have access to financial education and it is accompanied by participation in meaningful financial services [30].
Global policymakers have realized that low financial literacy is a barrier to national economic growth due to rising debt levels as a result of poor decision-making of individuals, and its impact to the global scale [14]. Thus, efforts are in progress to fill these gaps with specific programs to "identify individuals who are most in need of financial education and the best ways to improve that education" [26]. The best intervention for low-income countries is to facilitate and increase the use of financial services in order to avoid scams and unscrupulous providers by providing basic financial education [8] Therefore, a recommendation for the inclusion of financial education in the curriculum is a good strategy in improving financial knowledge, behavior and attitudes among students, by emphasizing on financial concepts and critical thinking skills and making it relevant to their modern lives. It is a long-term approach to financial literacy among teachers. In the long run, they make the most of opportunities, meet their goals and secure their financial wellbeing, as well as contribute to the economic health of society [13].

The percentage of correct answers in the basic financial literacy survey and the corresponding rank of the basic financial literacy skill of the professional and pre-service teachers are presented in Table 3. The data present the five (5) basic questions which aims to measure the basic but fundamental concepts relating to financial literacy, such as number numeracy, the working of compound interest rates, effects of inflation, time value of money and money illusion.

Professional teachers and pre-service teacher's results show that they performed better in number numeracy skills. This means that they can perform simple interest calculation which is a basic mathematical ability. However, pre-service teachers performed better than professional teachers at $67 \%$. This means that they readily demonstrated such computational skills since the topic is still fresh from their basic math and economics courses while the professional teachers are teaching their field of expertise forgetting their basic knowledge on numeracy. This implies that students and teachers could be competent enough in using their mathematical ability if provided with appropriate programs and trainings related to improving financial literacy. We strongly agree

\begin{tabular}{|c|c|c|c|c|c|}
\hline \multirow{2}{*}{$\begin{array}{l}\text { Basic Financial } \\
\text { Literacy Items }\end{array}$} & \multirow[t]{2}{*}{ Locale } & \multicolumn{2}{|c|}{ Professional Teachers } & \multicolumn{2}{|c|}{ Pre-service Teachers } \\
\hline & & $\begin{array}{l}\text { Correct Answers } \\
\text { (Percentage-\%) }\end{array}$ & Rank & $\begin{array}{l}\text { Correct Answers } \\
\text { (Percentage-\%) }\end{array}$ & Rank \\
\hline \multirow[t]{4}{*}{ Number Numeracy } & Luzon & 57.24 & & 58.18 & \\
\hline & Visayas & 59.47 & & 74.24 & \\
\hline & Mindanao & 61 & & 67.24 & \\
\hline & Total & 59.34 & 1 & 67.28 & 1 \\
\hline \multirow[t]{4}{*}{ Compound Interest } & Luzon & 28.89 & & 31.27 & \\
\hline & Visayas & 28.70 & & 35.46 & \\
\hline & Mindanao & 30.92 & & 32.05 & \\
\hline & Total & 29.57 & 3 & 33.15 & 4 \\
\hline \multirow[t]{4}{*}{ Inflation } & Luzon & 28.62 & & 30.91 & \\
\hline & Visayas & 34.02 & & 37.95 & \\
\hline & Mindanao & 25.06 & & 33.10 & \\
\hline & Total & 29.17 & 5 & 34.34 & 3 \\
\hline \multirow[t]{4}{*}{ Time Value of Money } & Luzon & 22.37 & & 26.18 & \\
\hline & Visayas & 29.29 & & 29.92 & \\
\hline & Mindanao & 35.38 & & 32.40 & \\
\hline & Total & 29.37 & 4 & 29.58 & 5 \\
\hline \multirow[t]{4}{*}{ Money Illusion } & Luzon & 44.74 & & 46.91 & \\
\hline & Visayas & 44.08 & & 64.82 & \\
\hline & Mindanao & 36.21 & & 48.08 & \\
\hline & Total & 41.46 & 2 & 54.28 & 2 \\
\hline
\end{tabular}

Table 3: Basic financial literacy skills of professional and pre-service teachers. 
that schools have an important role in the attainment of financial literacy among students Furthermore, experts believed that there is a place for the development of skill, knowledge and attitudes necessary for sound financial literacy within the school curriculum(ASIC, 2003).

The concept on money illusion ranked second to number numeracy for both groups. This means that both teachers and students failed to understand that the general increase in prices reduces the real purchasing power of the meager wages of teachers. Almost $50 \%$ of the teachers, whose wages were not as high with the other professions in the Philippines, did not comprehend the meaning of inflation when making financial decisions. The UK Financial Services Authority as mentioned by Hugo [31] concluded that people in low social classes and those with low incomes were the least sophisticated financial consumers.

Third in rank, is the concept on compound interest for professional teachers and fourth in rank among the pre-service teachers. Both groups have difficulty calculating interest of money compounded through the years. Though this topic is part of the curriculum in basic mathematics offered in school, however, they lack the knowledge and skill in applying this in concrete financial situation. This finding is alarming considering that teachers usually access to credit by borrowing money from family or friends when their income does not quite cover their living costs. Similar finding is revealed by Australia and New Zealand Banking Group (2005) when $67 \%$ of respondents said they understood compound interest, but a mere $28 \%$ were rated as having good level of comprehension when faced with an actual problem to solve. Lusardi and Mitchell [22] opined that students without understanding of the actual mathematics underlying interest compounding would find it difficult to explain the importance of starting to save early or how quickly debt grows when borrowing at the interest rates charged by credit cards companies or by payday lenders.

Theory on time value of money ranked fourth for professional teachers and ranked fifth for pre-service teachers. Both groups of respondents did not recognize the greater benefit of receiving money now rather than later which is the time value of money. Applying this concept to investment implies that teachers have not fully participated in investing process because they could not fully grasp the core principle of time value of money. Thus, they miss the opportunity of a favorable return of investments [22].

To sum, both professional and pre-service teachers are deficient in knowledge and skills of basic financial literacy. The lack of basic financial information and how to appropriately use these resources deduces ones financial choices which may result to poor financial decision making.

Sophisticated financial literacy of professional and pre-service teachers' survey results with their corresponding rank is shown in Table 4 . The table presents the eight (8) sophisticated financial literacy questions which aims to measure advance concepts relating financial

\begin{tabular}{|c|c|c|c|c|c|}
\hline \multirow{2}{*}{$\begin{array}{l}\text { Sophisticated Financial } \\
\text { Literacy }\end{array}$} & \multirow[b]{2}{*}{ Locale } & \multicolumn{2}{|c|}{ Professional Teachers } & \multicolumn{2}{|c|}{ Pre-service Teachers } \\
\hline & & $\begin{array}{c}\text { Correct Answers } \\
\text { (Percentage-\%) }\end{array}$ & Rank & $\begin{array}{c}\text { Correct Answers } \\
\text { (Percentage-\%) }\end{array}$ & Rank \\
\hline \multirow[t]{4}{*}{ Function of Stock Market } & Luzon & 27.96 & & 31.72 & \\
\hline & Visayas & 27.51 & & 45.15 & \\
\hline & Mindanao & 23.96 & & 49.13 & \\
\hline & Total & 26.37 & 2 & 42.25 & 2 \\
\hline \multirow{4}{*}{ Knowledge of Mutual Funds } & Luzon & 18.42 & & 26.91 & \\
\hline & Visayas & 24.55 & & 39.89 & \\
\hline & Mindanao & 21.17 & & 28.92 & \\
\hline & Total & 21.48 & 5 & 32.61 & 4 \\
\hline \multirow[t]{4}{*}{ Relationship between Interest Rates \& Bond } & Luzon & 16.77 & & 26.18 & \\
\hline & Visayas & 9.47 & & 26.32 & \\
\hline & Mindanao & 0 & & 39.02 & \\
\hline & Total & 8.29 & 7 & 30.23 & 5 \\
\hline \multirow[t]{4}{*}{ Safer: Company Stock Or Mutual Funds } & Luzon & 25.33 & & 31.64 & \\
\hline & Visayas & 3.25 & & 47.09 & \\
\hline & Mindanao & 33.70 & & 54.35 & \\
\hline & Total & 20.88 & 6 & 44.74 & 1 \\
\hline \multirow[t]{4}{*}{ Riskier: Stocks or Bonds } & Luzon & 0 & & 1.09 & \\
\hline & Visayas & 0 & & 0.55 & \\
\hline & Mindanao & 0 & & 1.04 & \\
\hline & Total & 0.00 & 8 & 0.86 & 8 \\
\hline \multirow{4}{*}{ Long Periods Returns } & Luzon & 21.83 & & 25.45 & \\
\hline & Visayas & 30.77 & & 28.53 & \\
\hline & Mindanao & 25.63 & & 15.68 & \\
\hline & Total & 25.87 & 3 & 23.62 & 7 \\
\hline \multirow[t]{4}{*}{ Highest Fluctuations } & Luzon & 28.29 & & 35.64 & \\
\hline & Visayas & 33.14 & & 34.63 & \\
\hline & Mindanao & 25.91 & & 28.57 & \\
\hline & Total & 29.07 & 1 & 33.04 & 3 \\
\hline \multirow[t]{4}{*}{ Risk Diversifications } & Luzon & 21.71 & & 19.64 & \\
\hline & Visayas & 23.08 & & 28.53 & \\
\hline & Mindanao & 22.84 & & 23.69 & \\
\hline & Total & 22.58 & 4 & 24.38 & 6 \\
\hline
\end{tabular}

Table 4: Sophisticated financial literacy of professional and pre-service teachers in the Philippines. 
literacy, such as function of the stock market, knowledge of mutual funds, relationship between interest rates and bond prices, safer returns of company stock or mutual fund, the risk of having stocks or bonds, long period return of money, effects of fluctuations and risk diversification.

In totality, the professional and pre-service teachers exhibited a very low sophisticated financial literacy. This means that they have not fully understood the effects of interest rates on one's saving and loans, and its direct impact on some people's income. This describes that they have not fully comprehend the role of stock market in investments and future profits, as well as the risk of stocks and bonds. They find risk diversification a difficult concept, in effect both professional and preservice teachers can't identify, explain and manage the risks on having stocks or bonds and the other risks in any investment instrument. This means that both teachers and students have insufficient knowledge on investments and do not appreciate their rights and responsibilities as consumers of financial products and services [8].

This finding implies that teachers have not invested in these types of products which normally allow people to make their fortune grow and they never took advantage of the prospective higher returns offered by the securities market. These teachers are busy with their work, have not attended financial seminars and trainings and have inadequate income to participate in sophisticated financial products and services available in the market. Reuters Surveys (2015) revealed that sub-index measuring overall knowledge about financial products, services and concepts, as well as ability to plan for long-term financial needs dropped in Philippines, Indonesia and Myanmar. Moreover, studies have shown that domestic workers' salaries have not increased substantially since 1994 to the present [32]. This is quite disturbing since these professional teachers have been in the profession for 10 to 20 years, almost near to retirement and yet, have not gained financial freedom. This might also be true to other professions in the country. Lusardi and Wallace [33] recognized financial literacy as a necessary skill to successfully navigate today's complex economic society.

Studies by the National Longitudinal Survey of Youth and Jumpstart Coalition for Personal Literacy have shown that many young people have little comprehension of finance and economics [34].

Similarly, the pre-service teachers very low sophisticated financial literacy means that they have insufficient knowledge on advanced financial literacy. John Hancock Financial Services Defined Contribution Plan Survey (2002) produced similar patterns when college employees, tourists, parents of students, and local construction workers, all knew little about mutual funds and they could not explain even simple differences between stocks, bonds, and money market mutual funds. As measured by FINRA [35] similar results were found in Germany, Netherlands, Sweden, Italy, Japan and New Zealand. This implies that there is a great need to include financial education in the curriculum. With this upsetting low financial literacy in the colleges and universities there is need to start identifying financial and quantitative skill by providing sufficient emphasis on financial topics in a practical context, and eventually to real, actionable financial decisions [33].

The strong need for financial education program is evident in this survey where the lack of awareness of certain financial products and services make the teachers vulnerable to poverty related concerns. Access to financial information equips everyone with how to better handle financial decisions in their lives. Moreover, more financially literate individuals increase the demand for the use of financial services, help to strengthen financial market stability, and contribute to wider economic growth and development of the country [8].

\section{Conclusion}

Financial literacy of professional and pre-service teachers in the Philippines is very low. Thus, financial illiteracy is common among educators which reflect their students' financial literacy skills and the economic condition of the majority of the Filipino people. Curriculum inclusion of financial education to both basic and higher education is recommended to improve the financial knowledge, behaviour and attitudes among teachers, students which, in turn, spells a better economic growth and development of the country.

\section{References}

1. Lusardi A, Mitchell $O$ (2011) "Financial Literacy Around the World: An Overview." Journal of Pension Economics and Finance.

2. Performance of International Student Assessment (PISA). (2012)

3. Lusardi A, Mitchell O (2007) "Financial Literacy and Retirement Preparedness Evidence and Implications for Financial Education."

4. Miles D (2004) The UK Mortgage Market: Taking a Longer-Term View. Working Paper.

5. Atkinson A, Messy F (2012) OECD Working Papers on Finance, Insurance and Private Pensions. ISSN: 2079-7117.

6. Financial Consumer Agency of Canada (FCAC)-OECD (2011) The Future of Financial Education.

7. World Bank (2009) The Case for Financial Literacy In Developing Countries

8. World Bank (2013) Financial Capability in Low- and Middle Income Countries: Measurement and Evaluation.

9. Organization for Economic Co-operation and Development (OECD).

10. Bernheim D, Garret DM (2003) The Effects of Financial Education in the Workplace: Evidence from a Survey of Households. Journal of Public Economics 87: 1487-1519.

11. Hung A, Yoong J (2010) Asking for Help: Survey and Experimental Evidence on financial Advice and Behavior Change. RAND Corporation Publications Department.

12. Lusardi A, Mitchell O (2009) Debt Literacy, financial Experiences and Overindebtedness. Mimeo Harvard Business School.

13. Australian Securities and Investments commission (ASIC) (2011). National Financial Literacy Strategy.

14. Rychwalski A (2011) Presentation FCAC-OECD Conference on Financial Literacy.

15. Inceptia Survey Reports (2013) First-Year College Students Score Poorly in Basic Financial Literacy.

16. Ramasawmy D, Thapermall S, Dowlut A, Ramen M (2013) Proceedings of $3^{\text {rd }}$ Asia-Pacific Business Research Conference, Malaysia.

17. Hilgert M, Hogart J, Beverly S (2003) "Household Financial Management: The Connection Between Knowledge and Behavior." Federal Reserve Bulletin, pp: 309-322.

18. Lusardi A, Mitchell O (2006) "Financial Literacy and Retirement Preparedness: Evidence and Implications for Financial Education."

19. Van RM, Lusardi A, Alessie R (2007) Financial Literacy and Stock Market Participation. MRRC Working Paper.

20. Calvert LE, Campbell JY, Sodini P (2009) "Measuring the FinancialSophistication of Households." National Bureau of Economic Research.

21. Cude JB, Frances CL, Angela CL, Kaci M, Emiley LJ, et al. (2006) College Students and Financial Literacy: What they Know and What We Need to Learn. Eastern Family Economics and Resource Management Association.

22. Lusardi A, Mitchell O (2006) Financial Literacy and Planning: Implications for Retirement Wellbeing. MRRC Working Paper.

23. Zokaityte A (2016) Financial Literacy and Numeracy of Consumers and Retail Investors. Capital Markets Law Journals.

24. Peters E, Judith H, Paul S, Nathan D (2007) Numeracy Skills and the 
Citation: Imelda CM, Angeline MP, Gwendelina AV, Genalen MP (2017) Financial Literacy of Professional and Pre-Service Teachers in the Philippines. J Glob Econ 5: 267. doi: 10.4172/2375-4389.1000267

Page 8 of 8

Communication, comprehension, and Use of Risk-Benefit Information. Health Affairs.

25. Chen H, Rao A (2007) When Two Plus Two Is Not Equal to Four in Processing Multiple Percentage Changes. Journal of Consumer Research.

26. Organization for Economic Co-operation and Development (OECD) (2005) Improving Financial Literacy: Analysis of Issues and Policies." Paris, France.

27. Willis L (2008) Against financial Literacy Education. IOWA Law Review.

28. Agnew J, Bateman H, Thorp S (2013) Financial Literacy and Retirement Planning in Australia. Numeracy.

29. Philippine Statistics Authority (2016) Quarterly Report.

30. Sherraden M, Johnson L, Elliot W, Guo B (2011) Financial Capability in
Children: Effects of Participation in a School-Based Financial Education and Savings Program. Financial Literacy and Education 32: 385-399.

31. Hugo N (2008) Overcoming the Saving Slump:How to Increase the Effectiveness of Financial Education and Saving Programs edited by Lusard Annamaria. Chicago: University of Chicago Press 9: 1-406.

32. Gonzales E (2007) Pagpapahalaga sa Perang Kinita: Pinoy's Guidie to Managing Finances. USAID, EPRA.

33. Lusardi A, Wallace D (2013) Financial Literacy and Quantitative Reasonibng in High School and College Classroom.

34. Mandell, Lewis (2004) Financial Literacy: Are WE Improving? JumpStart Coalition for Personal Finance Literacy.

35. FINRA Investor Education Foundation National Financial Capability Survey 